\title{
Approaching the Social History of Romanian Fascism
}

\section{The Legionaries of Vâlcea County in the Interwar Period}

\author{
Oliver Jens Schmitt \\ Professor, Institute of East European History, University of Vienna, Austria \\ oliver.schmitt@univie.ac.at
}

\begin{abstract}
This article explores fascist mobilization in Romania on a regional and local level. Focusing on the south-western Romanian county of Rîmnicu Vâlcea it combines qualitative analysis with the quantitative analysis of approximately 1,350 members of the Legionary Movement. Vâlcea provides an example of a district which was not a fascist stronghold: the fascist leader Corneliu Zelea Codreanu failed to establish a stable organizational network. Only when the local bishop actively supported small circles of young village intellectuals did fascist mobilization gain momentum. The overwhelming peasant majority of members joined the movement rather late (1937). This article concludes that there were differences between village intellectuals who believed in an ideological community of creed and peasant members who strove for social revolution.
\end{abstract}

\section{Keywords}

fascism - Romania - Legionary Movement - social history - Vâlcea

Comparative studies of European fascism in the interwar period have obtained an impressive level of sophistication. Over the last twenty years special attention has been paid to the analysis of fascist ideology and to theoretical interpretations of 'generic fascism'. The field of fascist studies is dominated by the

\footnotetext{
* This article was supported by the Open Access Publishing Fund of the University of Vienna.

(C) OLIVER JENS SCHMITT, 2014 | DOI 10.1163/22116257-00302005

This is an open access article distributed under the terms of the Creative Commons Attribution 3.0 
history of ideas and recent theories inspired by cultural studies. ${ }^{1}$ The gap between theoretical attempts at defining fascism and the negligence of documentary material in archives has become so striking that scholars, such as Sven Reichardt or Constantin Iordachi have expressed regret at this state of research. As Iordachi has recently noted theoretical debates on fascism were often divorced from empirical research; the definition of fascism became an aim in itself rather than a research tool.'2 Iordachi advocates a comparative entangled history of fascisms which does not exclusively rely on a German/Italian model and regional divergences from 'ideal' forms of fascism. He proposes studying fascism in East and South-East Europe without constant reference to a normative model based on Western examples.

Much ink has been spilt on the ideology of the Legionary Movement, the most important fascist phenomenon in South East Europe, and recently scholars have rightly pointed to its modern revolutionary character thereby overcoming orientalist ideas of a primitive rural Romania. ${ }^{3}$ One cannot but agree with approaches which de-orientalize the Legionary Movement and demonstrate the high degree of modernity contained in core elements of Legionary ideology. ${ }^{4}$ But still, scholars concentrate on propaganda texts and have so far,

1 For example, Roger Griffin, 'The Primacy of Culture: The Current Growth (or Manufacture) of Consensus within Fascist Studies,'Journal of Contemporary History 37 (2002):21-43; Marius Turda, 'Conservative Palingenesis and Cultural Modernism in Early Twentieth-century Romania,' Totalitarian Movements and Political Religions 9, no. 4 (2008): 437-53; Daniel Ursprung, 'Faschismus in Ostmittel- und Südosteuropa: Theorien, Ansätze, Fragestellungen,' in Der Einfluss von Faschismus und Nationalsozialismus auf Minderheiten in Ostmittel- und Südosteuropa, ed. Harald Roth and Mariana Hausleitner (Munich: Oldenbourg, 2006), 9-52; Alessandra Tarquini, Storia della cultura fascista (Bologna: Il Mulino, 2011).

2 Constantin Iordachi, 'Fascism on Southeastern Europe: A Comparison between Romania's Legion of the Archangel Michael and Croatia's Ustaša,' in Entangled Histories of the Balkans. Vol. 2. Transfers of Political Ideologies and Institutions, ed. Roumen Daskalov and Diana Mishkova (Leiden/Boston: Brill, 2014), 355-68, here 365; Sven Reichardt, 'Neue Wege der vergleichenden Faschismusforschung,' Mittelweg 36 16, no. 1 (2007): 9-25; cf. Armin Heinen and Oliver Jens Schmitt, 'Einführung,' in Inszenierte Gegenmacht von rechts: Die 'Legion Erzengel Michael' in Rumänien 1918-1938, ed. Armin Heinen and Oliver Jens Schmitt (Munich: Oldenbourg, 2013), 7-12.

3 For an assessment of the state of the art in the field of Legionary studies see Armin Heinen and Oliver Jens Schmitt, ed., Inszenierte Gegengewalt von rechts: Die 'Legion Erzengel Michael' im Rumänien 1918-1938 (Munich: Oldenbourg, 2013).

4 For the history of the Legionary movements see the classical works by: Armin Heinen, Die Legion 'Erzengel Michael' in Rumänien: Soziale Bewegung und politische Organisation (Munich: Oldenbourg, 1986); Francisco Veiga, Istoria Gărzii de Fier, 1919-1941: Mistica ultranaţionalismului (Bucharest: Humanitas, 1993); among recent scholarship see Roland 
with the notable exception of Irina Livezeanu, ${ }^{5}$ failed to produce a social history of the Legionary intelligentsia. The huge number of students associations, fascist practices and rituals in the intelligentsia milieu and the emergence of fascist circles in major provincial towns as Iaşi, Cluj or Cernăuţi have only partially been subject to in-depth analysis. ${ }^{6}$ Studies on the Legionary Movement are still much characterized by extrapolations - from the core group of radical students and intellectuals to the rest of the members, from Bucharest to the rest of the country. ${ }^{7}$

Clark, European Fascists and Local Activists: Romania's Legion of the Archangel, 1922-1928 (PhD diss., University of Pittsburgh, 2012), accessed March 18, 2014, http://d-scholarship.pitt .edu/11837/1/ETD_Thesis_-_Clark.pdf; for a thorough theoretical conceptualization see: Constantin Iordachi, 'Charisma, religion, and ideology: Romania's Interwar Legion of the Archangel Michael,' in Ideologies and National Identities: The Case of Twentieth-Century Southeastern Europe, ed. John R. Lampe and Mark Mazower (Budapest, New York: CEU Press, 2004), 15-53.

5 Irina Livezeanu, Cultural Politics in Greater Romania: Regionalism, Nation Building \& Ethnic Struggle, 1918-1930 (Ithaca: Cornell University Press, 1995).

6 There are however numerous works on the history of universities e.g. Istoria universităţii din Iaşi, ed. Gheorghe Iacob and Alexandru Florin Platon (Iaşi: Editura universităţii A.I. Cuza, 2010); the recent history of extreme right-wing extremism at universities is provided by the introduction to Lucian Năstasă, ed., Antisemitismul universitar în România, 1919-1939: Mărturii documentare (Cluj-Napoca: Kriterion, 2011); Lucian Năstasă, Die Unmöglichkeit des Andersseins: Überlegungen zum universitären Antisemitismus in Rumänien, 1920-1940,' Jahrbuch für Universitätsgeschichte 4 (2001): 54-67.

7 Leon Volovici, Nationalist Ideology and Antisemitism: The Case of Romanian Intellectuals in the 1930s (Oxford: CRC Pr. Inc., 1991); Zigu Ornea, The Romanian Extreme Right: The Nineteen Thirties (Boulder: East European Monographs, 1999); Alexandra Laignel-Lavastine, Cioran, Eliade, Ionesco: L'oubli du fascisme (Paris: PUF, 2002); Florin Ţurcanu, Mircea Eliade: Le prisonnier de l'histoire (Paris: La découverte, 2003); Patrice Bollon, Cioran der Ketzer (Frankfurt am Main: Suhrkamp, 2006); Sorin Lavric, Noica şi miscarea legionară (Bucharest: Humanitas, 2007); Marta Petreu, Diavolul şi ucenicul său: Nae Ionescu - Mihail Sebastian (Bucharest: Polirom, 2009); Marta Petreu, De la Junimea la Noica: Studii de cultură românească (Iaşi: Polirom, 2011); Mircea Platon, "The Iron Guard and the "Modern State": Iron Guard Leaders Vasile Marin and Ion I. Moţa, and the "New European Order", Fascism:Journal of Comparative Fascist Studies 1 (2012): 65-90, accessed August 28, 2014, http://booksandjournals.brillonline .com/content/journals/10.1163/22116257-00201002; recent publications as Radu Harald Dinu, Faschismus, Religion und Gewalt in Südosteuropa: Die Legion Erzengel Michael und die Ustaša im historischen Vergleich (Wiesbaden: Harrassowitz, 2013) do not really offer new perspectives since they focus on comparison in a research discussion where at least the Romanian case has to be studied for its own sake before a thorough comparison relying on a firm empirical base can be conducted. 
There are numerous reasons which justify small-scale approaches to South East European fascism - but the most striking one is the lack of methodologically rigorous case studies. For the Legionary Movement we possess monographs on Bucovina, the Dobruja and Bessarabia which are very descriptive in their narrative structure. ${ }^{8}$ Several rather short articles try to highlight cases on the level of the județ [county]. ${ }^{9}$ Yet none of these studies operate with models of social history that have been introduced into studies of German and Italian fascisms. Indeed, apart from several fragmented pieces of evidence, we have no thorough statistical data on the social composition and social dynamics of the Legionary Movement. Leading scholarship in the field has certainly provided numerous valuable insights, but these remain at the national level. To sum up: what Mircea Eliade and Emil Cioran thought of Codreanu's movement is now well known, but we do not possess a single study of how these ideas were transported from student circles to the large mass of rural adherents of the movement. Put simply, we still do not really know who the Romanian fascists were outside of small elite groups and prominent individuals. ${ }^{10}$ Almost thirty years ago, Detlef Mühlberger observed that 'there is practically no reliable data on the forces that shaped the villagers' outlook and political allegiance in the various areas of the country.'11 Now the Romanian archives are open, research can begin.

A better understanding of the social structure of the Legionary Movement has to be combined with analysis of the mechanisms of transmission which linked the early nuclei of the movement with new social and spatial areas of mobilization. This article therefore proposes an approach that combines quantitative data with an examination of the local socio-cultural setting. Although it has been almost totally ignored so far, statistical material is available in a considerable number of Romanian states archives and the Consiliu naţional pentru studierea arhivelor Securităţii [CNSAs; Securitate archive]. Statistics for Romanian fascists on a regional level have to be corroborated by evidence from

8 Viorica Nicolenco, Extrema dreaptă în Basarabia, 1923-1940 (Chişinău: Civitas, 1999); Puiu Dumitru Bordeiu, Mişcarea legionară în Dobrogea între 1933-1941 (Constanţa: Ex ponto, 2003); Radu Florian Bruja, Extrema dreaptă în Bucovina (Târgovişte: Cetate de Scaun, 2012).

9 Florin-Răzvan Mihai, 'Activitatea Mişcării Legionare în judeţul Covurlui (1927-1933): Lideri locali, tehnici de propagandă, succese electorale,' Erasmus 15 (2006-2009): 47-6o

10 Cf. Michael Mann, Fascism (Cambridge: Cambridge University Press, 2004), 15-17, 266-72.

11 Detlef Mühlberger, ed., The Social Bases of European Fascist Movements (London: Croom Helm, 1987), 299. 
documentary sources. These mainly consist of police reports which have to be placed in a regional setting, i.e. within the social, economic and political structures of Vâlcea County. ${ }^{12}$ The analysis has to be further informed by regional scholarship which provides essential background for the historical context. Regional historiography is supported by the county museum in Vâlcea and publications by local historians. An up-to-date village monograph has recently been published by a group of historians from Sibiu University for the commune of Călimăneşti. ${ }^{13}$

On a theoretical level, this case study relies on an impressive tradition of scholarship on the social history of fascist movements. ${ }^{14}$ Of particular importance are regional case studies which combine quantitative and qualitative evidence (because of the loss of statistical data for many parts of Fascist Italy,

12 I thank my colleague Sorin Radu, University of Sibiu, for providing me with relevant bibliographies: Radu Livezeanu, Scurtă privire asupra vieţii organizaţiei Partidului National-Ţărănesc din judeţul Vâlcea între anii 1919-1998 (Râmnicu-Vâlcea: Conphys, 1999); Corneliu Tamaş, Istoria Râmnicului (Râmnicu-Vâlcea: Antim Ivireanu, 1994); Sorin Oane, Liberalismul Vîlcean: Istorii vechi și noi (Rîmnicu-Vîlcea: author's edition, 2013). I thank Sorin Oane for a pdf of his monograph. Ion M. Ciucă, ed., Aspecte din viaţa economică, socială şi politică a judeţului Vâlcea în perioada 1918-1940 (Drăgăşani: Kitcom, 2006); Sorin Oane, Istoria Judeţului Vâlcea 1948-1965: Un studiu de caz (Râmnicu Vâlcea: Conphys, 2007); Sorin Oane, 'Schiţa partidelor şi doctrinelor politice din judeţul Vâlcea în perioada interbelică,' Studii vâlcene, new series no. 1 ( 2003): 15288; cf. also Ana-Maria Rădulescu, Conservatorii din judeţul Dolj (Craiova: Aius, 2005); Sorin Oane is also the author of internet resources such as Istorie Locală which provides rich material on local history, accessed March 18, 2014, http://www.istorielocala.ro/index .php? option $=$ com_k2\&view $=$ item\&id=200:v\% $\% \mathrm{C}_{3} \%$ A2lcea- $\% \mathrm{C}_{3} \%$ AEn-perioada -interbelic\%C4\%83-1918-1938\&Itemid $=203$.

13 Sorin Radu, Vasile Ciobanu and Radu Racoviţan, ed., Călimăneşti: Monografie istorică şi etnografică (Bucharest: Editura Spandugino, 2009).

14 Wolfgang Schieder, 'Die NSDAP vor 1933: Profil einer faschistischen Partei,' Geschichte und Gesellschaft 19, no. 2 (1993): 141-54; Jürgen W. Falter, Michael H. Kater, 'Wähler und Mitglieder der NSDAP: Neue Forschungsergebnisse zur Soziographie des Nationalsozialismus 1925 bis 1933,' Geschichte und Gesellschaft 19, no. 2 (1993): 155-77; Michael Kater, The Nazi Party: A Social Profile of Members and Leaders 1919-1945 (Cambridge: Harvard University Press, 1983); Jürgen W. Falter, Zur Soziographie des Nationalsozialismus: Studien zu den Wählern und den Mitgliedern der NSDAP (Cologne: GESIS, 2013), in particular: 'The Young Membership of the NSDAP between 1925 and 1933. A Demographic and Social Profile': 260-79, and 'Die "Märzgefallenen" von 1933: Neue Forschungsergebnisse zum sozialen Wandel innerhalb der NSDAP-Mitgliederschaft während der Machtergreifungsphase': 280-302; Wolfgang Benz, ed., Wie wurde man Parteigenosse? Die NSDAP und ihre Mitglieder (Frankfurt am Main: S. Fischer, 2009). 
methodological models were elaborated mainly for Germany). ${ }^{15}$ This study is thus situated both in international fascist studies and in Romanian research traditions.

The article explores fascist mobilization in Romania on a regional and local level and provides empirical evidence about the means and mechanisms of mobilization. It focuses on the movement period during Corneliu Zelea Codreanu's leadership and does not include the period of Legionary dictatorship (September 1940- January 1941). This is not to deny continuity between the two phases (opposition - regime), but our concern is mainly the opposition period and the question of how a radical revolutionary movement was able to penetrate into the structures of rural Romania's highly conservative society.

This study is divided into two main parts. In the first part special emphasis is placed on the transmission of Legionary ideology and practices from Legionary centers outside Vâlcea County. This process is closely related to the emergence of local leaders. The interaction between Vâlcea activists with the nationwide movement deserves special attention. The second part analyzes the social composition of the Legionary Movement. Data is interpreted at the county level, but we will also try to refine our research model by focusing in on local strongholds.

\section{Why Vâlcea?}

Vâlcea is a county that belongs to the so-called Regat or 'Old Kingdom'. Situated to the north-west of the Romanian capital Bucharest, this county is part of the historical region of Oltenia, i.e. the western part of the former principality of Valachia which united with the principality of Moldavia in 1859 and formed the new principality (since 1881 Kingdom) of Romania. Until 1918 Vâlcea was a border county at the frontier with Austria-Hungary. After the unification of former Habsburg lands with Romania, the county shifted to the core of 'Greater Romania'.

Socially and culturally, the county was extremely homogenous. Around $99 \%$ of its inhabitants were Orthodox Romanians, and there were virtually no minorities (unlike Moldavia and Bucovina, the early strongholds of the

15 Anne Becker and Detlef Mühlberger, 'The Sociography of the Nazi Party in a Catholic County: The 1939 Census of the Membership of the NSDAP in County Aachen,' Totalitarian Movements and Political Religions 6, no. 2 (2005): 243-69. The authors provide references to key texts in the field. 
Legionary Movement). The county's capital Rîmnicu Vâlcea was an exception with its $10 \%$ Jewish population (mainly immigrants that had arrived during the first decades of the twentieth century). With its compact socio-cultural structures Vâlcea was typical for rural Valachia. According to the Romanian National Encyclopedia, the population was composed of two sociocultural groups: pământeni [autochthonous] and ungureni, the latter being descendants of Romanian immigrants from neighbouring Transylvania which belonged until 1918 to the Hungarian Crown. The ungureni settled mainly in the upper part of the county and concentrated on cattle breeding. Ethnographers described them as more industrious than the pământeni. Vâlcea stood out, even for Romanian standards, with its huge number of monasteries, schiti [hermitages] and churches, some of them belonging to the oldest and most important sacred foundations in Romania, such as the monasteries of Cozia (founded in 1386), Govora (1491/92), Bistriţa (1518), Arnota (1640) and Horezu (1692). Ethnographers of the interwar period have insisted on this particular cultural feature and depicted Vâlcea as bulwark of Romanian national identity and folk traditions. Vâlcea's place in the national imaginary was also due to its landscape. The county with a surface of $4,081 \mathrm{~km}^{2}$ stretched from the mountain range of Parângu in the north (up to 2,00o m) over a hilly area at the slopes of the Carpathian mountains to the periphery of the Oltenian plane ${ }^{16}$ and represented a combination of Alpine traits and those rolling hills that were glorified as essential to the Romanian mentality by interwar intellectuals like Lucian Blaga. ${ }^{17}$ The county was also defined topographically by rivers which rise from the Carpathians and run southwards to the Danube. The main river Olt constitutes the eastern demarcation of the county; all major settlements, the county capital Rîmnicu Vâlcea included, are located on the river Olt.

In 1930 Vâlcea counted 246,616 inhabitants whose number grew to 273,634 by 1937 . Vâlcea was an eminently rural region; only $13.4 \%$ of its inhabitants lived in settlements that were officially categorized as urban. Rîmnicu Vâlcea had only 15,00o inhabitants, all other major settlements less than 10,000 inhabitants. The county was divided into the districts (plasă, pl. Plăşi) Cerna, Cozia, Drăgăşani, Horezu and Olteţu. Vâlcea was a predominantly agrarian area. Apart from agriculture (mainly corn) and cattle breeding in the mountain part

16 Dimitrie Gusti, ed., Enciclopedia României, vol. 2 (Bucharest: Imprimeria naţională, 1938), 505 .

17 Klaus Heitmann, “Das rumänische Phänomen”: Die Frage des nationalen Spezifikums in der Selbstbesinnung der rumänischen Kultur seit 1900,' Südost-Forschungen 29 (1970): $171-236$. 
of the district, modest domestic tourism in spas and wood industry characterized the regional economy. ${ }^{18}$

In national terms, Vâlcea was not a Legionary stronghold. In the elections of 1931 and 1932 the Legionaries were virtually non-existent. In the elections of December 1937, while the Legionary party Totul pentru Ţară [Everything for the Fatherland] obtained $15.58 \%$ of the vote across the country, in Vâlcea they scored $11.35 \%$. That Vâlcea constituted a region that fell slightly under the national average of Legionary mobilization potential makes for an interesting case study. Furthermore, its ethnically (almost) homogenous character makes it a case for studying radical tendencies within Romanian society which were not influenced by regional competition with other ethnic/religious groups. Until now, the research focus has been on core groups of Romanian fascists (students and intellectuals) and, with less emphasis, on major centers (university towns, Bucovina, Moldavia).

Existing historiography insists on political diversity and divergences in interwar Romania which are explained by deep structural differences between former Habsburg and Russian provinces and the Regat. ${ }^{19}$ By choosing Vâlcea we penetrate into the core lands of the Old Kingdom which traditionally supported the government party in elections. ${ }^{20}$ Vallcea also belonged to the core land of the Partidul Național Țărănesc [PNT; National Peasant Party], one of the most serious political adversaries of Romanian fascism. In 1945 the National Peasant Party had around 10,000 members in Vâlcea County. ${ }^{21}$ The PNT and the Liberal Party controlled most of Vâlcea's interwar political life, the party in power always winning the election according to the Romanian system of 'guided democracy' which offered the party in government the so called 'electoral dowry' (majority of seats for a party winning more than $40 \%$ of votes; and voter intimidation). ${ }^{22}$

18 Enciclopedia României, vol. 2, 508.

19 For an excellent analysis cf. Constantin Iordachi, 'Faschismus, Charisma und Politik: Die Legion 'Erzengel Michael" im Zwischenkriegsrumänien 1927-1941,' in Inszenierte Gegenmacht von rechts, 20-68, here $26-32$.

Sorin Oane, 'Vâlcea în perioada interbelică (1918-1938),' Istoria Locală, August 6, 2012, http://www.istorielocala.ro/index.php?option =com_k2\&view $=$ item\&id=20o:v\% $\mathrm{C}_{3} \% \mathrm{~A} 2$ lcea- $\% \mathrm{C}_{3} \%$ AEn-perioada-interbelic $\% \mathrm{C}_{4} \% 83-1918-1938 \&$ Itemid $=203, \quad$ accessed March 18, 2014; cf. the analysis of Stelu Şerban, Elite, partide şi spectru politic în România interbelică (Bucharest: Paideia, 2006)

21 Armin Heinen, 'Wahlmaschine: Die Legion "Erzengel Michael”, die Wahlen 1931-1937 und die Integrationskrise des rumänischen Staates,' in Inszenierte Gegenmacht von rechts, 144-45.

22 Hans-Christian Maner, Parlamentarismus in Rumänien (1930-1940) (Munich: Oldenbourg, 1997), 5 . 
Vâlcea was linked to Bucharest by a number of leading politicians who won their seats in the county; the most prominent is certainly Ion Gheorghe Duca (1879-1933) who had served as judge in the village of Horezu and was elected as Member of Parliament for Vâlcea several times. ${ }^{23}$ In December 1933 he was murdered by members of the Legionary Movement. ${ }^{24}$ Among Vâlcea's prominent political representatives were also Andrei Livezeanu, of the National Peasant Party, and his brother Andrei who in 1934 became vice-president and in 1938 leader of the Party's youth organization. His fellow party member Dinu Simian was elected vice-president of the first Chamber of Parliament and under-secretary of State. ${ }^{25}$ But Legionary leaders also had strong personal ties to Vâlcea: General Gheorghe Cantacuzino-Grănicerul (1869-1937) whom Corneliu Zelea Codreanu appointed head of the Legionary Party in 1935 had been elected in 1920/21 MP for Vâlcea for the People's Party, a populist movement led by Romania's Général Boulanger, Marshal Alexandru Averescu (1859-1938). Radu Demetrescu-Gyr (1905-1975), Legionary leader of Oltenia and a prominent intellectual of the movement, had married a woman from Vâlcea. ${ }^{26}$

Despite its rural and agrarian character, Vâlcea was thus not a completely peripheral area in Greater Romania. This becomes clearer still if we relate political and socio-economic developments in the county to broader developments on a national level. Vâlcea not only followed major trends in elections by voting constantly for the winning parties, it was also exposed to major changes in Romanian society. Agrarian reform was introduced by 1921 following peasant discontent, but its implementation was hampered by various problems. Vâlcea's overwhelming peasant majority was severely hit by the world economic crisis at the beginning of the 1930 s which aggravated structural problems: ${ }^{27}$ literacy $(50.3 \%)$ was under the national average, and there was a considerable gender gap (male 71.2\%; female 31.5\%). A major government offensive in education led to an increase of the number of teachers from 616 in 1933 to 718 in 1936 but this did not drastically change the situation. In the early

23 Liliana Beu, 'Câteva repere privind originile şi familia omului politic I.G. Duca,' Buridava 5 (2007): 135-41.

24 For an excellent discussion of the highly disputed background of this political murder see Ovidiu Buruiană, Construind opoziţia: Istoria politică a partidului naţional liberal între anii 1927 şi 1933, (Iaşi : Editura universităţii “Alexandru Ioan Cuza”, 2013), 564-77.

25 Oane, 'Vâlcea în perioada interbelică.'

26 Ibid.

27 Cf. Gheorghe Dumitraşcu, 'Aspecte privind mişcarea muncitorească din judeţul Vîlcea în anii crizei economice (1929-1933), Buridava 4 (1982): 171-79. 
1930s, drought, and hail damaged agriculture and viticulture, and cattle breeding was in crisis. Industry had developed only modestly; wood processing by a number of timber mills held an important place, but few factories could absorb labor from the villages. In October 1931 the newspaper Îndrumarea Villcii summarized the situation: lack of credit; lack of demand for agricultural products; indebted peasant households; bankruptcy of enterprises; increasing unemployment. In 1933 the most important factories (Societatea Carpantina, Brezoiu) had reduced their production by $33 \%$ compared to 1925 or even by $60 \%$ (tabacco factory and tannery in Rîmnicu Vâlcea). Unemployment and social misery led repeatedly to strikes and demonstrations at local level. ${ }^{28}$ Public health was, quite typical for interwar Romania, also a serious problem with high rates of tuberculosis $(1,328$ cases in 1932$)$ and syphilis $(2,910$ cases in 1932). ${ }^{29}$ 'Spirits were troubled', as police reports put it, by the general crisis of the country and news of major corruption cases (such as the Škoda scandal) that reached rural parts of Vâlcea. It is against this background that the rise of the Legionary Movement has to be studied.

Finally, there is an important practical reason for studying Vâlcea: it still is the only county where the Legionary Movement can be studied on the basis of serial data on membership from the interwar period. Another recent case study concerning south-east Valachia relies only on files containing data on local Legionary leaders (not normal party members). ${ }^{30}$

\section{The Emergence of the Legionary Movement in Vâlcea}

In September 1932 Corneliu Zelea Codreanu visited Rîmnicu Vâlcea where he met several army veterans, two high school teachers, a lawyer, three students, a typographer, and two persons without profession. This meeting represented the founding of the movement in the county. But Legionary activity was beset by internal conflict which soon paralyzed the minuscule group. It was a conflict marked by a generational gap and questions of prestige. The core group of high school teachers favoured one of them, Professor Vasile Nicolău, while students supported a young lawyer, Victor Bărbulescu. Codreanu tried to resolve the conflict by appointing a military retiree, Colonel Stelian Drăgoescu in

28 Dumitraşcu, 'Aspecte,' $171-72$.

29 Oane, 'Vâlcea în perioada interbelică.'

30 Oliver Jens Schmitt, 'Wer waren die rumänischen Legionäre? Eine Fallstudie zu faschistischen Kadern im ruralen Umland von Bukarest (1927-1941), Vierteljahreshefte für Zeitgeschichte (in print). 
December 1932. It soon became evident that Drăgoescu clung to the antiSemitic traditions of the Liga apărări naţionale creştine [LANC; League of National-Christian Defense] led by Codreanu's former mentor and since 1927 political concurrent Alexandru Constantin Cuza. ${ }^{31}$ Codreanu had to remove the colonel whose ideological competence left a lot to be desired. Codreanu replaced him with the village priest Gheorghe Doară who succeeded in setting up the preliminary organizational structures of the Iron Guard - the party organization of the Legionary Movement. Doară distributed propaganda material which he received directly from the Legionary center in Bucharest; local activists reproduced well-known slogans against freemasonry and government violence against 'students', i.e. members of the Legionary Movement. ${ }^{32}$

As we will see more in detail, in Vâlcea in 1933, the Iron Guard consisted mainly of students, priests, teachers and employees. The movement may have profited from public unrest on a national scale, ${ }^{33}$ but numerically, with its sixty-seven members, it was still a marginal group in $1933 \cdot{ }^{34}$ Moreover, after the murder of Vâlcea-related Prime Minister Ion Gheorghe Duca, authorities cracked down on regional leaders of the Iron Guard which at that time was active in only a few communes of the county. In February 1934, Romanian Gendarmerie forces launched an extensive manhunt in the Parângu mountains in the Northern part of Vâlcea; all houses, cottages and stables were searched, but without any result. ${ }^{35}$ There were no Legionaries in hiding in the snow covered mountains, since most of them were imprisoned in Rîmnicu Vâlcea awaiting their trial. ${ }^{36}$ On 7 February 1934 the police released the Legionary priests of Tetoiu and Tomşani, three students of Theology and the chanter of the church of Stroeşti, while the priest of Stroeşti, Gheorghe Doară, was still detained. ${ }^{37}$

31 Horia Bozdoghină, Antisemitismul lui A.C. Cuza în politica românească (Bucharest: Curtea veche, 2012); Lucian T. Butaru, Rasism românesc: Componenta rasială a discursului antisemit din România, până la al doilea război mondial (Cluj-Napoca: Editura Fundaţiei pentru Studii Europene, 2010).

32 Direcţia Arhivelor Nationale Istorice Centrale (DANIC), Direcţia generală a Poliţiei, dossier 102/1933, 81 .

33 Consiliu naţional pentru studierea arhivelor Securităţii (CNSAS), dossier D 19733 vol. 1 (Privind problema legionară 1932-1939), 1.

34 DANIC, Inspectoratul general al Jandarmeriei, dossier 20/1935, 256.

35 DANIC Inspectoratul general al Jandarmeriei, dossier 14/1932, 174-75.

36 CNSAS, dossier D 19733 vol. 1, 4-5.

37 CNSAS, dossier D 19733 vol. 1, 45. 
Significantly, it was at that time that first public demonstrations of sympathy occurred. In September 1934 police reports stated that imprisoned Legionaries were playing football, chess and other games; that they were offered plenty of excellent food by the local population; that the 'entire population' brought them money, trousers, shirts and socks; that local butchers provided them with fresh meat and pharmacists with medicine. There was even a committee which coordinated these acts of solidarity, and its chairman was no less a figure than the bishop of Rîmnicu Vâlcea himself, Vartolomeu Stănescu $\left(1875^{-1954)}\right)^{38}$ Stănescu's support was all the more emblematic because in 1934 the Iron Guard was still suppressed and Legionary activities were illegal. While Stănescu openly demonstrated his sympathy with the Legionaries, the fascists themselves were keeping a low profile and restricted their activities to wordof-mouth propaganda.

The local bishop had evolved into a key player in regional politics because he had given shelter to a hardly disguised Legionary congress in Rîmnicu Vâlcea in August 1934. ${ }^{39}$ Since the 1920 s student conferences had served as propaganda forums for fascist activists in Romania. The Legionary Movement had grown out of radicalized student movements, and at the beginning of the 1930s, students still constituted the core group of fascist mobilization. The congress in Rîmnicu Vâlcea was organized by the student association of Olt, Oltenia and Timoc. Although the Minister of Interior and the Rector of the University of Bucharest had refused permission, Legionary activists began to arrive in Rîmnicu Vâlcea in mid-August 1934. Among them were the leading propagandists Mihail Stelescu; Sandu Valeriu, president of the student associations of Moldavia; and Tiana Siliman from Botoşani (Moldavia), the fiancée of Nicolae Constantinescu, one of the murderers of Prime Minister Ion Gheorghe Duca. That the conference was far more than a local meeting became obvious when fascist activists from Bucharest, from Moldavia (Vaslui, Buzău), Transylvania (Sibiu) and Valachia (Ploeşti) and Dobruja (Constanţa) were registered by the police - many of them were former members of the so called 'death squads', an elite unit of the Legionary Movement. The guests were welcomed by local activists (approximately seventy students, a lawyer and a retired army officer). They were offered accommodation in the Episcopal dormitory where they put on their green shirts which they had secretly brought with them. Bishop Stănescu celebrated a Te-Deum for the participants of this illegal congress, he tolerated the equally illegal green shirts and he opened seminary rooms for the conference discussions. The authorities intervened in

38 DANIC, Direcţia generală a Poliţiei, dossier 102/1933, 246.

39 Sorin Oane, 'Episcopul Râmnicului, Vartolomeu Stănescu,' Buridava 6 (2008): 164-72. 
order to stop what rapidly turned into an open defiance of the law. The prosecutor summoned Stelescu and a student delegation to leave Rîmnicu Vâlcea with the next train, but around two hundred Legionary students gathered and formed marching columns. When police and gendarmerie forces tried to stop them, Stelescu ordered the students to carry out a sit-in. Eventually forty-nine students were arrested, thirty-nine were sentenced in an ensuing trial. ${ }^{40}$

\section{A 'Green' Bishop and the Rise of the Legionary Movement in Vâlcea}

The events of 1934 - the student conference and the support committee for arrested Legionaries - proved to be decisive in boosting the Legionary Movement in Vâlcea County. ${ }^{41}$ Vâlcea constitutes a particularly interesting case study because it was the local bishop whose open support triggered the rapid rise of the fascist movement. The Legionary leader Corneliu Zelea Codreanu was too weak to build up structures in an area which was a political terra incognita to him. His visit had attracted local high school teachers and some retired officers, but they lacked social prestige and especially socio-economic resources. Vartolomeu Stănescu's support radically changed the situation. This ambitious clergyman had decided to foster Legionary activities in order to promote his own political ambitions - Radu Gyr, the regional Legionary leader and highly influential ideologist, even dreamt of designing Bishop Stănescu as future Patriarch of Legionary Romania. ${ }^{42}$ The bishop actively encouraged village priests to disseminate Legionary ideas, and he was deeply involved in the Legionary propaganda offensive of 1936. It is noteworthy that Codreanu did not visit Vâlcea a second time. Vâlcea became rather the fief of two men, Bishop Stănescu and Radu Demetrescu-Gyr, the leading Legionary poet whose wife came from Vâlcea County.

Bishop Stănescu had been appointed bishop of Rîmnic and Noul Severin in 1921. The bishopric of Rîmnic had a longstanding tradition of politically active clergy. A recent study underlines that most bishops who ex officio were members of the Romanian Senate were deeply involved in party politics. ${ }^{43}$ Vartolomeu Stănescu was no exception to this rule. He belonged to those Orthodox theologians who showed a keen interest in processes of social

$40 \quad$ CNSAS, dossier D 19733 vol. 1, 2-3, list on $57-58$.

41 DANIC, Inspectoratul general al Jandarmeriei, dossier 20/1935, 256.

42 DANIC, Direcţia generală a Poliţiei, dossier 232/1935, 305.

43 Ciprian-Marius Sîrbu, 'Episcopii Râmnicului şi viaţa politică românească în perioada 1859-1918,' Buridava 10 (2012): 162-87. 
change. He was familiar with Catholic social political theories and had published a treatise on 'social Christianity'. In his bishopric, he tried to reorganize the impoverished clergy and became a leading spokesman of the association Renaşterea [Rebirth] which was founded in October 1921 and rallied around nine hundred priests from Oltenia. He established a priest seminary in Rîmnicu Vâlcea and established a printing center in Cozia monastery. In 1929 he supported the foundation of the 'People's bank for priests' in Vâlcea County and the creation of cooperative. Stănescu was thus an experienced organizer who had set up his own regional infrastructure of power. He was also a gifted manager and businessman; in order to finance his projects, he had increased taxes for ecclesiastical services, and he was repeatedly accused of corruption.

His finest hour came in May 1935 when Petrache Lupu, a herdsman in the village of Maglavit on the Danube, pretended to have communicated several times with God. News of Petrache Lupu's vision spread rapidly over the entire country and provoked a mass hysteria. Within a few weeks, tens of thousands pilgrims poured in the village. Stănescu came to Maglavit in September 1935 to venerate the new shrine of Orthodoxy, and alongside local priests took control over the commercial dimension of what promised to become the Romanian Lourdes. Later on, the Legionaries built a 'green house' in Maglavit. ${ }^{44}$ Stănescu acted and behaved as regional political patron who oppressed any opposition within the clergy and instrumentalized village priests and church institutions for Legionary propaganda. He was a talented organizer, a shrewd businessman, but also a theologian with intellectual ambitions. He was a able to channel social unrest and messianic expectations which found their expression in the events of Maglavit for his own political goals. That he was a controversial figure became all too clear, when in December 1936, a bomb exploded in front of the Episcopal palace. ${ }^{45}$ After the suspension of the Constitution on 8 February 1938, Stănescu was deposed and confined in a monastery until his death. ${ }^{46}$

Legionary mobilization under the official guidance of the local bishop was a unique case in interwar Romania. Critically he raised the visibility and the prestige of local fascists in the eyes of the rural population. He encouraged

44 Oane, 'Episcopul Râmnicului,' 165-69; Florin Müller, 'Das Wunder von Maglavit,' in Religion im Nationalstaat zwischen den Weltkriegen 1918-1939, ed. Hans-Christian Maner and Martin Schulze Wessel (Stuttgart: Steiner 2002), 189-97.

45 DANIC, Direcţia generală a Poliţiei, dossier 46/1937, 93-95, the police investigation remained without results.

46 On Bishop Vartolomeu Stănescu see cnSAs, dossier D 19733 vol. 1, 17-20. The Communist Securitate described him as 'moral guide and material supporter' of the Legionary Movement. 
village priests who enrolled in the movement and he officially consecrated Legionary activities as 'work camps'. He was invited by Legionary intellectuals to inaugurate a series of public lectures in Bucharest (January 1937).

In summer 1936, Radu Demetrescu-Gyr, Legionary commander of Oltenia (which figured as region XI in the Legionary organization of Romania) drafted a report on Legionary activities for the 'căpitan' Corneliu Zelea Codreanu. ${ }^{47}$ Radu Gyr, as he is usually called, was the bard of the Legionary Movement; he composed the text of the Legionary anthem 'Holy Legionary youth' and several other key songs of the movement. Gyr belonged to the inner circle of the movement and secured close contacts between the center in Bucharest and local structures in Oltenia, and Vâlcea in particular.

In 1936, the Legionary Movement had started a huge campaign in rural Romania. Originally the Iron Guard had tried to win over peasants with military marches, aggressive rhetoric and violent acts against political opponents. But since 1935 Codreanu and his entourage had promoted a strategy of 'constructive work' in so called 'work camps' where Legionaries constructed or renovated churches, schools, mountain huts, roads, and fountains. Very often, members of the local population joined the Legionaries in these activities. ${ }^{48}$ These 'work camps' constituted the fascist breakthrough in areas where the Legionaries had been virtually absent before. Building activities and the erection of crucifixes were also aimed at occupying public space with Legionary symbols.

Already, in 1935, Vâlcea had become a target region for this strategy when student teams had constructed a work camp in the monastery Arnota where they deployed intensive propaganda. ${ }^{49}$ The Arnota camp was particularly important because it conveyed high cultural prestige; the second important camp was established in the commune of Drăgăşani, a Legionary stronghold, where a church dedicated to the Dormition would be erected. ${ }^{50}$

A year later, in summer 1936, Radu Demetrescu-Gyr analyzed thirteen work camps and building sites which rooted the movement at a local level. The dimension of the projects varied between cleaning cemeteries (as in Voiceşti); the creation of public parks (as in Târgul Bălceşti); digging wells for fountains (in Stefăneşti, Prundeni, Diculeşti); constructing a center of meditation close to the monastery Arnota; mountain huts (on mount Mamu); a primary school

47 CNSAS, dossier D 19733 vol. 1, 81-86.

48 Rebecca Haynes, 'Work Camps, Commerce, and the Education of the "New Man" in the Romanian Legionary Movement,' The Historical Journal $5^{1}$ (2008): 943-67.

49 DANIC, Inspectoratul general al Jandarmeriei, dossier 20/1935, 256.

50 CNSAS, dossier D 19733 vol. 1, 3-4. 
(in Tomşani); a church (in Tetoiu); a bell tower (in Olteanca) or a chapel (in Guşoeni). The most important work camp was organized by the Vâlcea leader Victor Bărbulescu in his native commune of Drăgăşani. In several villages, priests and school teachers led or supported these activities. In Tomşani, the local priest and teacher and many children took part in the renovating the school. In Guşoeni, Demetrescu-Gyr emphasized the discipline of local peasants who took part in Legionary activities. The number of Legionary participants in the work camps greatly varied between two hundred or so in Drăgăşani (where the average daily presence varied between seventeen and seventy-five) to eight Legionaries who built a public park in Târgul Bălceşti. Legionary priests such as Gheorghe Doară in Stroeşti or Aurică Nicolescu were key figures in this mobilization campaign on the ground. Vâlcea was thus part of a nationwide Legionary offensive, and as in other counties, the Legionaries achieved their goal in Vâlcea: they became entrenched in those village societies where they had convinced local populations of the value of 'practical work', which according to Legionary ideology distinguished Legionaries from other political formations.

As in other parts of Romania, in early 1937, the burial of Ion Moţa and Vasile Marin (two members of the Legion's inner circle, who had died as volunteers in Francisco Franco's Army in the Spanish Civil War), boosted the Legionaries' prestige outside the Legionary milieu. When the train with their dead bodies passed through the station of Rîmnicu Vâlcea, a large crowd gathered, among them members of the Liberal and the National Peasant Party who attended out of curiosity. ${ }^{1}$

By 1937 the Vâlcea unit was structured according to models elaborated in Bucharest: a statul major [general staff] comprised the county leader, priest Gheorghe Doară, two aide-de-camps, a head of propaganda and a county judge of the Legionary party; there was an official responsible for health questions and another for church and school issues; the 'Cross fraternities' - the youth organization of the Legion - were represented by their regional leader and a secretary. As with the national level, the Legionaries had also a 'Senat' composed of six members on a regional level, three of whom were priests, one a doctor and one a retired army officer.

In February 1937, there were fifteen 'Legionary instructors' in the county, four of whom were village priests. ${ }^{52}$ The territory of Vâlcea was divided into

$5^{1}$ CNSAS, dossier D 19733 vol 1, 4; Valentin Săndulescu, 'Sacralised Politics in Action: the February 1937 Burial of the Romanian Legionary Leaders Iona Moţa and Vasile Marin,' Totalitarian Movements and Political religions 8 (2007): 259-69. 
eight districts (plasă; Cozia, Govora, Horezu, Oltul, Cerna, Olteţul, Drăgăşani, Bălceşti), four of whom were under the leadership of local priests. Vâlcea had at that time eighty-eight cuib ['nests'; basic unit with 3-13 members) with a total of 467 members. The Legionary party was able to gather five hundred Legionaries on a rally in Horezu during the election campaign in December 1937; thus, the Legion was able to mobilize more people than average government or National Peasant Party rallies. ${ }^{53}$ In December 1937 the Legionary party obtained 5,567 votes in Vâlcea, and in February 1938, when the Legionary party 'Everything for the Fatherland' was dissolved, the authorities registered around $1,35^{0}$ members. Police reports refer to propaganda methods which the Legionaries also applied nationwide: personal contacts, erection of crucifixes, participation at weddings and burials, establishment of Legionary shops, the collection of old iron, work camps, and so on. Most members of the movement were according to police reports young intellectuals, employees and children 'without experience and seriousness.'54

That said, the Legionaries were, even at their zenith in early 1938, not able to cover the entire Vâlcea County with their political structures. As we have seen, in the county capital Rîmnicu Vâlcea, high school teachers were the first group receptive to Legionary propaganda. On a regional level, the bishop's support was essential because it facilitated open political activity of village priests. But the Legionaries were neither on a national nor on a regional level a clerical fascist movement: despite their high visibility clergymen did never play a dominant role in the ranks of the Legionaries. ${ }^{55}$

53 DANIC, Inspectoratul general al Jandarmeriei, dossier 15/1937, 8, on 12 December 1937, the rallies of the government were attended by $80-100$ persons in three villages, $50-60$ persons in two villages and $50^{-}-70$ in five villages; in Băbeni four hundred people attended a meeting of the government party; the National Peasant Party mobilized more modest numbers of partisans (ca. one hundred in two villages, 20-25 in other two villages and twenty in one village).

54 CNSAS, dossier D 19733 vol. 1, 4.

55 Matthew Feldman and Marius Turda, "Clerical Fascism" in Interwar Europe: An Introduction,' Totalitarian Movements and Political religions 8 (2007): 205-12, especially 209; cf. Roger Eatwell, 'Reflections on Fascism and Religion,' in Religious Fundamentalism and Political Extremism, ed. Ami Pedahzur and Leonard Weinberg (Special issue of Totalitarian Movements and Political Religions 4, no. 3 (2003)): 23-26. The discussion about the relation of the Romanian Orthodox Church and the Legionary Movement has produced an impressive bibliography: Mirel Bănică, Biserica ortodoxă română: Stat şi societate în anii 'zo (Iaşi: Polirom, 2007); Roland Clark, Nationalism, Ethnotheology, and Mysticism in Interwar Romania (Pittsburgh: The center for Russian and East European Studies, 2009); Radu Harald Dinu,'The Legionary Movement between "political religion" 
The vast majority of their elite were secular, and a closer analysis of Legionary mobilization at the local level will confirm this impression. Let us start with the commune of Drăgăşani, with its 7,300 inhabitants, one of the biggest agglomerations in the county. The small town had a mill, five small banks, two high schools, a girls professional school, five primary schools, a kindergarten, a cinema, a small hospital, two churches and a synagogue. ${ }^{56}$ Legionary ideas were imported from outside, more precisely from Bucharest, by a student, Victor Bărbulescu, who had joined the Legionary Movement in Bucharest. In 1933 he had recruited the local priest Necşulescu who had formerly been a member of the National Peasant Party. In 1933 both men convinced some inhabitants to adhere to the movement, but when Bărbulescu and Necşulescu were arrested after the Duca murder (December 1933), the movement was still of minor importance. While Necşulescu was released after an intervention of the Liberal party, Bărbulescu who did not enjoy the support of non-Legionary networks remained in the prison of Jilava where he got acquainted with many leading Legionaries. After his release he returned to Drăgăşani and won three advocates for the Legionary cause. In 1935 they were joined by a former student of the Conservatory in Iaşi. In 1936 they established a 'work camp' for the renovation of the church of the Dormition. This increased their social prestige considerably, not least because members of the local society had supported them. Radu Demetrescu-Gyr recommended Bărbulescu to Corneliu Zelea Codreanu as an exemplary leader. In 1937, Bărbulescu was appointed leader of the party in the county. In the same year, he moved to the county capital. Police reports depict him as violent and ambitious. ${ }^{57}$ Bărbulescu transformed Drăgăşani into one of the Legionary strongholds in Vâlcea.

and "collective effervescence"', Arhivele Totalitarismului 16, no. 3-4 (2008): 16-25, in particular 17; Mihai Chioveanu, 'Arhanghelul acestei lumi: Legionarismul ca religie politică,' Studia politica: Romanian Political Science Review 7 (2007): 555-82; Olivier Gillet, 'Orthodoxie et extrêmes droites en Roumanie des années 1930: L'ultranationalisme contemporain,' Traverse 7 (2000): 44-55; George Enache, 'Église, société, nation, état en Roumanie pendant l'entre-deux-guerres: L'Église Orthodoxe Roumaine et "la tentation du totalitarisme droitiste”, Revistă Teologică 94 (2012): 301-26; Ionuţ Florin Biliuţă, 'Between Orthodoxy and the Nation: Definition of Romanianness in Interwar Romania' (Masterthesis Central European University, Budapest, 2007), available at http://www.etd .ceu.hu/2007/biliuta_ionut.pdf, accessed July 14, 2014.

56 Enciclopedia României vol. 2, 513.

57 CNSAS, dossier D 19733 vol. 2, 5, 9. 


\section{Quantifying Vâlcea's Legionaries}

The qualitative analysis we have offered in the first part of this study does not considerably differ from well-known methodological approaches in Romanian fascist studies. General impressions from police reports on social structure and mobilization techniques have also been described in other regional case studies. ${ }^{58}$ The second part of my paper will examine quantitative aspects of Legionary mobilization. The analysis is based on lists of Legionaries drafted by district police offices immediately after the suspension of the Constitution, i.e. in February/March 1938. It is not clear whether they are based on confiscated data of the Legionary Movement itself or on police investigations. In any case, these sources have to be analyzed with care. While the 1938 statistics correspond to the high-point of pre-War Legionary mobilization in Vâlcea, we also possess data concerning earlier stages of the movement. We will first present data for the period between 1933 and 1937 and then focus on the 1938 statistics. When working with statistical data, the construction of categories is of critical importance because there are regional differences in statistical accuracy. This study uses categories derived from both the empirical material and from categories defined for the purpose of our analysis. Professional categories such as 'peasant', 'priest', 'teacher,' 'student', 'high school pupil' derive from source language, while categories such as 'traditional crafts' (carpenters, tailors etc.), 'modern crafts' (non-academic technical professions as electricians), 'liberal professions' (lawyers, doctors) aggregate source categories.

There is no internal differentiation according to social and economic status for major groups such as peasants. This is particularly problematic for interpreting the huge majority of peasant members of the Legionary Movement we have no clue if Legionaries represented rather well-to-do farmers or more marginal elements within village society. However, education is subject to internal differentiation. Interwar statistics categorize different levels of education: primary education (6 classes), secondary education, professional education and tertiary education (university). But one has to be careful when interpreting data on primary education because the data indicates categorization rather than attendance at school. If a person is classified into the category ' 4 years of primary school', we cannot deduce automatically that this person was indeed fully literate.

$5^{8} \quad$ For exemple: Bruja, Extrema dreaptă în Bucovina. 


\section{Members and Sympathizers of the Iron Guard in Vâlcea County (June 1934)}

In June 1934, police reports registered eighty-one members of the Iron Guard and fifty-six sympathizers. Sympathizers were people who had personal contact with Corneliu Zelea Codreanu (a doctor, a high school professor, a priest); who had given donations to the Legionary Movement; who had supported legionaries during their trial in Rîmnicu Vâlcea (eight people, among them three priests); or who had simply declared their sympathy (the overwhelming majority of this category). It is important to underline that 'sympathizers' was a category constructed by state authorities and that it is used here to reconstruct political tendencies.

This structure is rather typical for the early stage of the Legionary Movement: peasants who will later, in 1938 , constitute around $70 \%$ of all members appear in modest numbers $(14.58 \%)$. Students ( $0.2 \%$ of population in rural areas of Vâlcea) are as overrepresented (15.39\%) as clergymen (priests and chanters, $11.34 \%$ ). Unfortunately, we do not have data on age. So called 'village intellectuals' (priests and teachers) figure prominently next to students. These groups

TABLE 1 Members and sympathizers of the Iron Guard in Vâlcea County (June 1934).

\begin{tabular}{lccr}
\hline & Members & Sympathizers & Total \\
\hline Students: & 19 & 2 & 21 \\
Peasants: & 18 & 24 & 42 \\
Priests: & 12 & 7 & 19 \\
Pensioners & 8 & 1 & 9 \\
Traditional crafts: & 8 & 2 & 10 \\
Pupils: & 5 & 4 & 9 \\
Employees: & 3 & 3 & 6 \\
Liberal professionals: & 3 & 2 & 5 \\
Teacher: & 2 & 4 & 6 \\
Chanters: & 2 & 0 & 2 \\
Freeholder: & 1 & 1 & 1 \\
Modern crafts: & 0 & 1 & 1 \\
Civil servant: & 0 & 5 & 137 \\
Tradesmen & 0 & 56 & 5 \\
Total & 81 & & \\
& & &
\end{tabular}




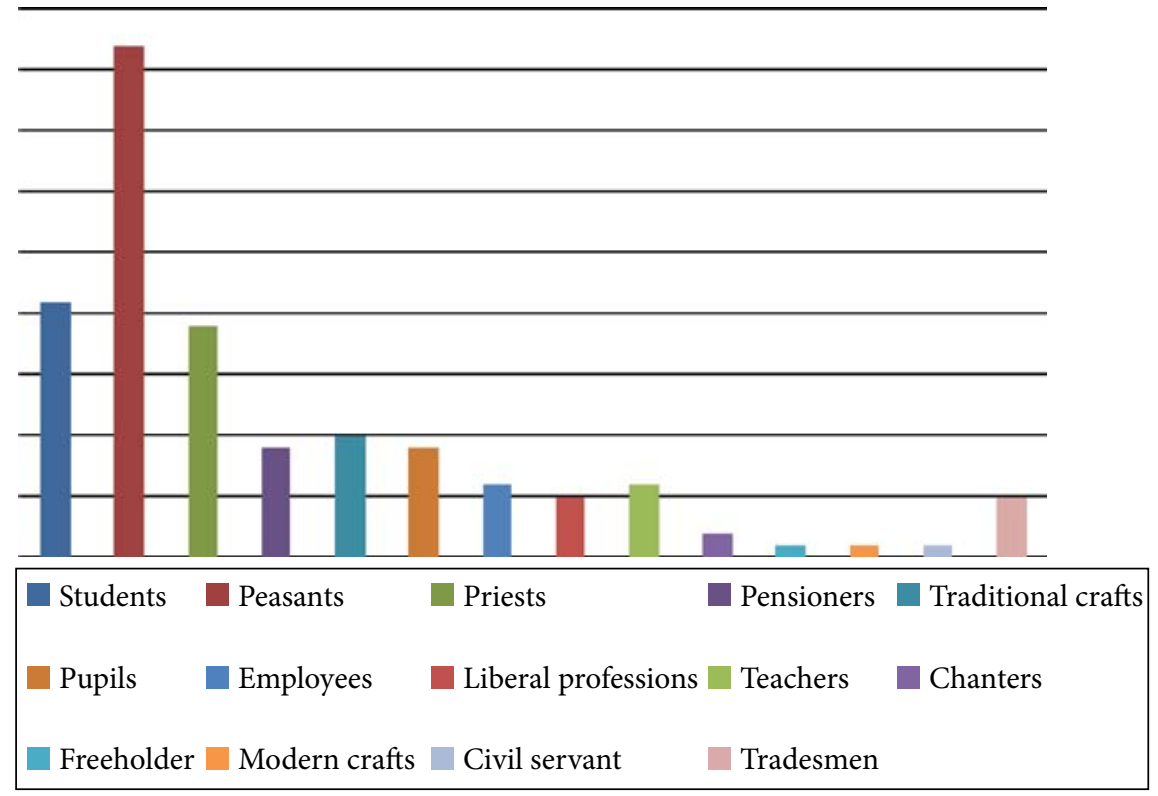

served as transmission elements between Legionary centers outside Vâlcea County and regional settlements. In its first year of existence, the Legionary Movement was unable mobilize outside these core groups.

\section{Spatial Distribution of Support: Vâlcea County in the First Half of 1937}

A second set of data was confiscated by police forces on 28 June 1938 in the house of a Legionary. The list is not dated, but clearly reflects an earlier stage of development ( 467 members). It can be assumed that this data was collected in the first half of 1937. These statistics are particularly interesting because they provide data collected by the movement itself and not by state authorities. Unfortunately, they only allow a reconstruction of the number of basic units (nests) and their spatial distribution (see Table 2).

This statistics illustrate the uneven spatial distribution of the Legionary Movement which had a direct impact on the structure of basic units. Legionaries mobilized mainly in the lower part of Vâlcea county along the river Olt (where population density was of course highest), but the concentration in Drăgăşani has to be explained with the activity of the local leader (and later leader of Vâlcea) Victor Bărbulescu. 
TABLE 2 Spatial distribution of the Legionary Movement.

\begin{tabular}{lclcc}
\hline District & Members & Leader (Profession) & Number of Nests & $\begin{array}{c}\text { Average Member/ } \\
\text { nest }\end{array}$ \\
& & & & 6.9 \\
\hline Plasă Cozia & 76 & lawyer & 11 & no data \\
Plasă Govora & no data & priest & no data & $5 \cdot 3$ \\
Plasă Horezu & 53 & priest & 10 & 10 \\
Plasă Oltul & 20 & lawyer & 2 & $5 \cdot 1$ \\
Plasă Cerna & 67 & officer in retiree & 13 & $3 \cdot 3$ \\
Plasă Olteţul & 27 & priest & 8 & 8.96 \\
Plasă & 224 & lawyer & 25 & \\
Drăgăşani & & & & 5.4 \\
Plasă Bălceşti & 98 & priest & 18 & 6.4 \\
Total & 467 & & 88 & \\
\hline
\end{tabular}

SOURCE: CNSAS, DOSSIER D 19733 VOL. 1, 109-11

An important consideration is the average ratio of member to basic unit. Corneliu Zelea Codreanu had declared that the 'nest' should comprise between three and thirteen members. The reality of this system has until now been known only in rudimentary form. Data for Vâlcea reveals different degrees of mobilization which can be correlated with the size of basic units. In Plasă Olteţul no basic unit had more than five members; in lowland Plasă Bălceşti numbers vary between three (Valea mare) and ten (Băbeni, Diculeşti with a Legionary priest). Drăgăşani as the regional center had a high ratio, but the same is true for Oltul where the modest number of twenty members were organized in two nests.

\section{The Apogee of Mobilization in the Codreanu Period (February 1938)}

The most thorough data is provided by statistics drafted by gendarmerie and police units in spring 1938.59 The statistics contain 1,347 individual cases for the whole county. The median of age is 31.7 years. The average Legionary in Vâlcea was thus slightly older than the average member of the NSDAP. There were

59 CNSAS, dossier D 19733 vol. 1, 114-37. 
TABLE 3 Professions of Legionaries Vâlcea February 1938.

\begin{tabular}{lcc}
\hline Peasants & 984 & $73.26 \%$ \\
Students & 80 & $5 \cdot 9 \%$ \\
Traditional crafts* & 70 & $5 \cdot 21 \%$ \\
Priests & 44 & $3.27 \%$ \\
Teachers & 45 & $3 \cdot 34 \%$ \\
Liberal professions & 28 & $2.08 \%$ \\
Workers & 24 & $1.78 \%$ \\
Chanters & 23 & $1.71 \%$ \\
Employees & 21 & $1.56 \%$ \\
Modern crafts** & 7 & $0.52 \%$ \\
Others & 17 & $1.26 \%$ \\
& \\
( ${ }^{*}$ carpenters, tailors etc.; ${ }^{* *}$ mainly technicians $)$ \\
N = 1343
\end{tabular}

SOURCE: CNSAS, DOSSIER D 19733 VOL. 1, 114-37

almost no women (ten) which does not surprise in a predominantly rural area and also because of the general low participation of women in political parties in other European countries.

This data illustrates the profound changes that the movement underwent between 1935 and 1938: the Legionaries had successfully penetrated village society. Although the number of peasant Legionaries is lower than the total percentage of peasants in Vâlcea society, they had become the demographic backbone of the movement. Students, priests and teachers are still overrepresented in comparison with their statistical position in the society, but the group of village intellectuals had clearly lost numerical dominance.

Education reflects the agrarian and rural dimension of the region (see Table 4).

TABLE $4 \quad$ Education of Legionaries Vâlcea February 1938.

\begin{tabular}{lll}
\hline Illiterates & 15 & $1.12 \%$ \\
1 class primary school & 1 & $0.07 \%$ \\
2 classes primary school & 29 & $2.16 \%$ \\
3 classes primary school & 60 & $4.46 \%$ \\
4 classes primary school & 492 & $36.61 \%$
\end{tabular}


TABLE 4 Education of Legionaries Vâlcea February 1938. (cont.)

\begin{tabular}{lrl}
\hline 5 classes primary school & 492 & $36.61 \%$ \\
6 classes primary school & 4 & $0.3 \%$ \\
High school & 50 & $3 \cdot 72 \%$ \\
Seminary (priests) & 43 & $3.2 \%$ \\
Teachers' College & 49 & $3.65 \%$ \\
Commercial school & 24 & $1.79 \%$ \\
University & 62 & $4.61 \%$ \\
Professional school & 9 & $0.67 \%$ \\
Others & 14 & $1.04 \%$ \\
$\mathrm{~N}=1344$ & & \\
\hline
\end{tabular}

SOURCE: CNSAS, DOSSIER D 19733 VOL. 1, 114-37

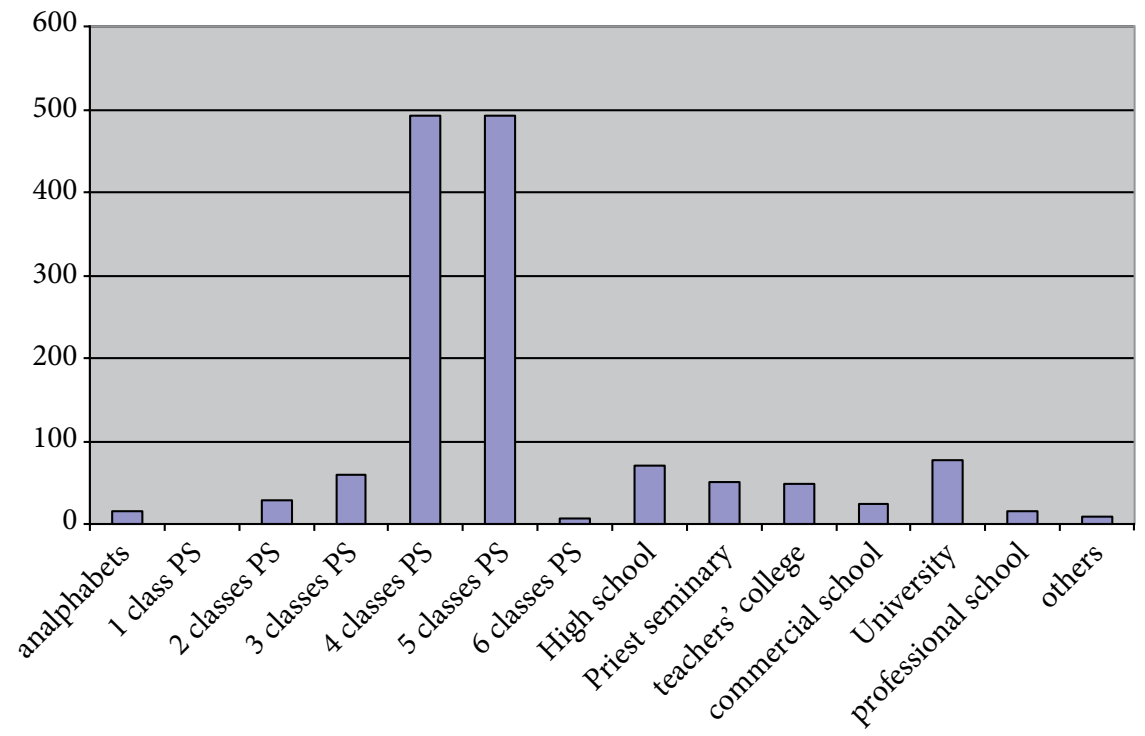

$80.04 \%$ of the Legionaries had attended primary school, most of the others went through secondary higher education. $13.25 \%$ had enjoyed tertiary education (university, professional and commercial schools, teachers and priest seminary). This data can easily be related to the overwhelmingly rural and agrarian structure of party membership. 
TABLE 5 Rank and file of Vâlcea Legionaries

\begin{tabular}{lrl}
\hline Nest leaders & 55 & $4.09 \%$ \\
Plasă leader & 1 & $0.07 \%$ \\
Sector leader & 4 & $0.3 \%$ \\
Aide de camp & 3 & $0.22 \%$ \\
Member & 1278 & $95.02 \%$ \\
\hline
\end{tabular}

SOURCE : CNSAS, DOSSIER D 19733 VOL. 1, 114-37

The Legion of the Archangel Michael and its party representation 'Everything for the Fatherland' were highly hierarchical organizations. As already noted, the 'nest' served as basic unit, followed by plasă (a group of nests often corresponding to the state administrative unit of the same name) and sectors.

Social structure and education of party leaders emerge from the data in Table 6.

It is far from surprising that village intellectuals, craftsmen and liberal professions are overrepresented in the group of Legionary leaders: in fact, the structure of Legionary leaders in 1938 reminds us of the Legionary core group of 1934. The dominance of these groups is even more striking if we analyze profession/rank: $97.25 \%$ of all peasants were normal members, while priests (79.55\% normal members), technicians $(85.71 \%)$ and teachers $(88.89 \%)$ were

TABLE 6 Education and professions of Legionary leaders Vâlcea February 1938.

\begin{tabular}{lrll}
\hline Education & \multicolumn{3}{l}{ Profession } \\
\hline 2 classes: & $3.64 \%$ & Peasants & $40 \%$ \\
3 classes & \multicolumn{1}{c}{0} & Priests & $10.91 \%$ \\
4 classes & $18.18 \%$ & Teachers & $7.27 \%$ \\
5 classes & $38.18 \%$ & Traditional crafts & $7.27 \%$ \\
High school & $5.45 \%$ & Modern crafts & $1.82 \%$ \\
Teachers' college & $7.27 \%$ & Employees & 0 \\
Seminary & $12.73 \%$ & Liberal professions & $9.09 \%$ \\
Cantors' school & $1.82 \%$ & students & $9.09 \%$ \\
University & $9.09 \%$ & workers & $3.64 \%$ \\
Theology & $1.82 \%$ & & \\
Commercial school & $1.82 \%$ & & \\
N=63 & & & \\
& & &
\end{tabular}

SOURCE: CNSAS, DOSSIER D 19733 VOL. 1, 114-37 


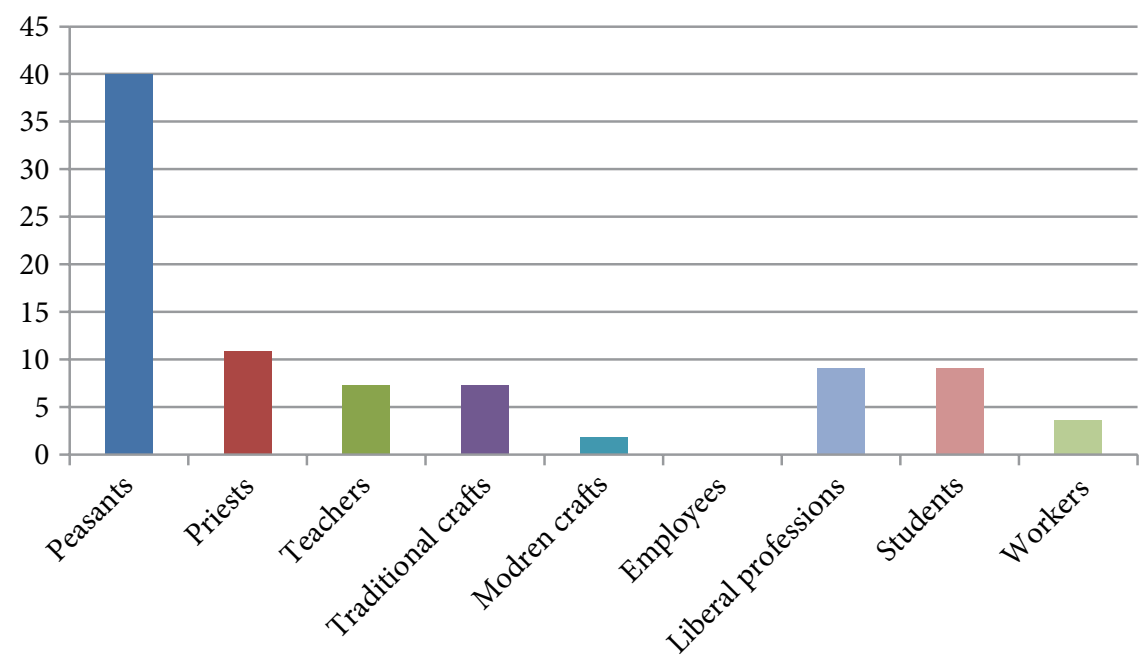

$\mathrm{N}=63$

TABLE 7 Education of Legionary leaders in Vâlcea February 1938.

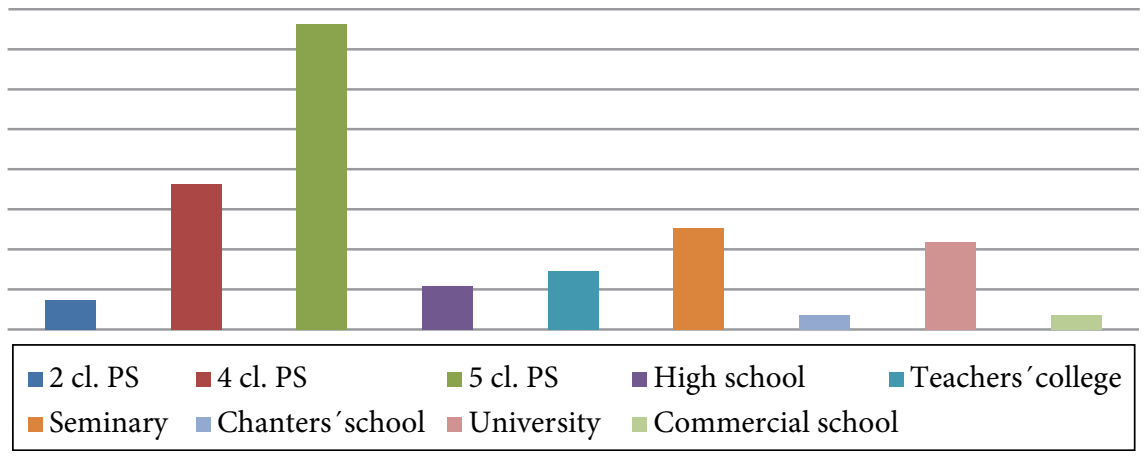

SOURCE: CNSAS, DOSSIER D 19733 VOL. 1, 114-37

much better represented in the higher party echelon (between approx. $11 \%$ and $20 \%$ ). These findings differ from the results of a case study of Legionary leaders in Greater Bucharest area (1927-1941) where mobilization reached its peak likewise in 1937 , but where peasants constituted $65.5 \%$ of local leaders. ${ }^{60}$

Vâlcea leaders did not feature an age structure that differed radically from ordinary members. There were however clear differences in occupation profile between leaders and members. Village intellectuals did not automatically recover leading positions. The vast majority of normal members were

60 Schmitt, 'Wer waren.' 
TABLE $8 \quad$ Professions of local Legionary leaders, Greater Bucharest area 1927-1941.

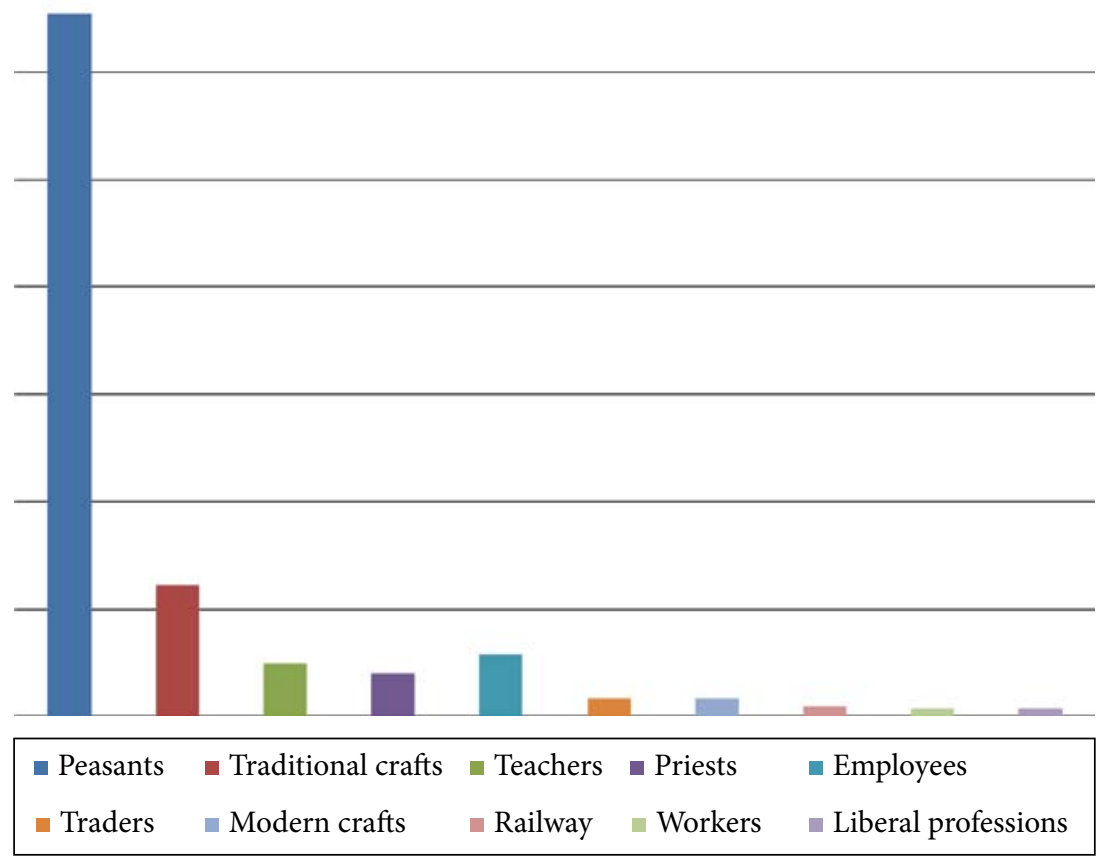

$\mathrm{N}=1517$

SOURCE: SCHMITT, 'WER WAREN.'

TABLE 9 Age nest leaders in Vâlcea, February 1938.

\begin{tabular}{lr}
\hline $20-25$ & $16.36 \%$ \\
$25-35$ & $58.18 \%$ \\
$35-45$ & $16.37 \%$ \\
$45^{-55}$ & $7.28 \%$ \\
Over 55 & $1.82 \%$ \\
\hline
\end{tabular}

SOURCE: CNSAS, DOSSIER D 19733 VOL. 1, 114-37 
TABLE 10 Occupation of ordinary members Vâlcea County February 1938.

\begin{tabular}{lrr}
\hline Peasants & 955 & $74.96 \%$ \\
Priests & 35 & $2.75 \%$ \\
Teachers & 40 & $3.14 \%$ \\
Traditional crafts & 66 & $5.18 \%$ \\
Modern crafts & 6 & $0.47 \%$ \\
Chanters & 17 & $1.33 \%$ \\
Employees & 21 & $1.65 \%$ \\
Liberal professions & 22 & $1.73 \%$ \\
Students & 74 & $5.81 \%$ \\
Workers & 22 & $1.73 \%$ \\
$\mathrm{~N}=1278$ & & \\
\hline
\end{tabular}

SOURCE: CNSAS, DOSSIER D 19733 VOL. 1, 114-137

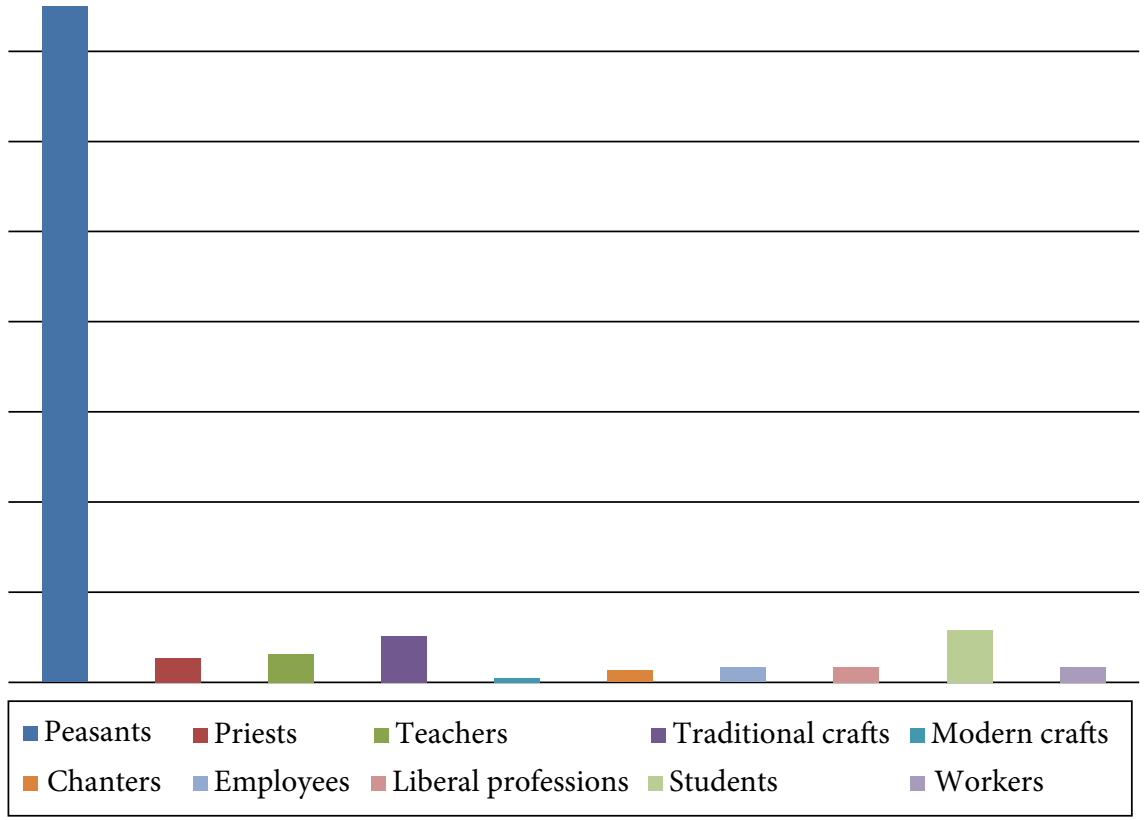

$\mathrm{N}=1278$ 
TABLE 11 Education of ordinary members Vâlcea County February 1938.

\section{Ordinary members: Peasants/education}

1 class primary school

2 classes primary school

3 classes primary school

4 classes primary school

5 classes primary school

6 classes primary school

High school

University

Commercial school

$\mathrm{N}=1278$

$$
\begin{gathered}
0.1 \% \\
2.75 \% \\
5.9 \% \\
43.54 \% \\
43.44 \% \\
0.31 \% \\
1.12 \% \\
0.2 \% \\
0.61 \%
\end{gathered}
$$

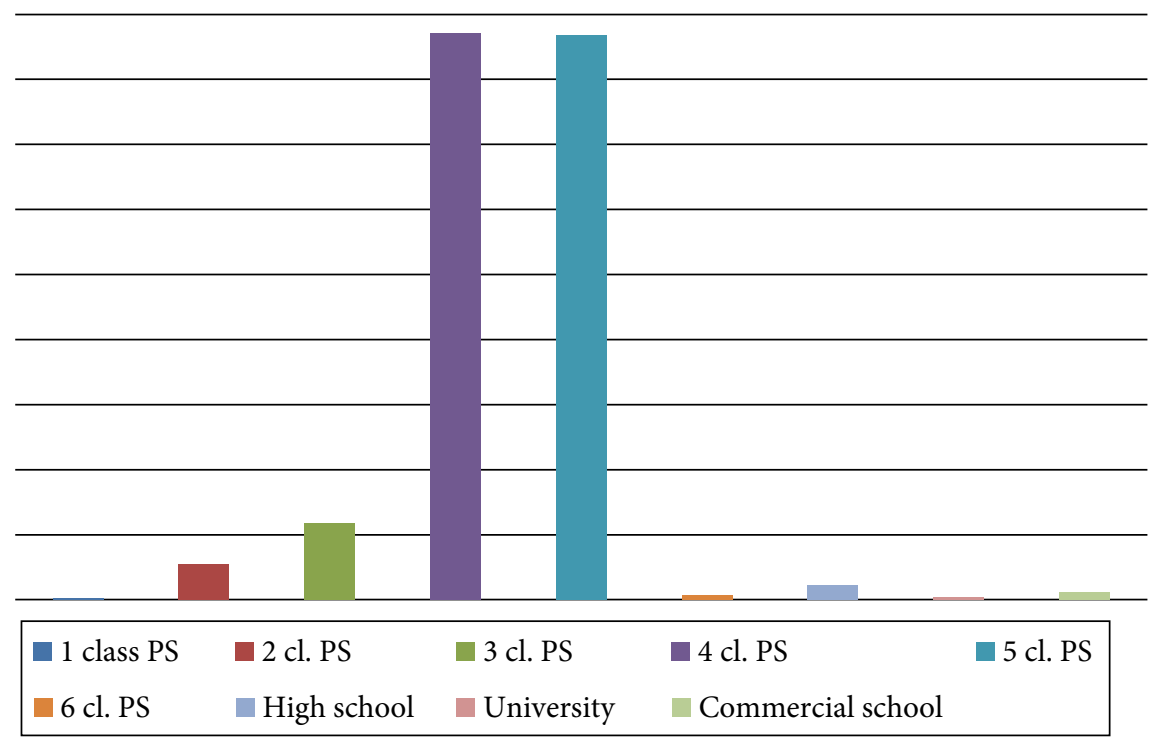

$\mathrm{N}=1278$ 
TABLE 12 Ordinary members: artisans and employees and their education.

\begin{tabular}{llll}
\hline Artisans traditional & \multicolumn{3}{c}{ Employees } \\
\hline 2 classes primary school & $=1.43 \%$ & 4 classes primary school & $=23.81 \%$ \\
4 classes primary school & $=38.57 \%$ & 5 classes primary school & $=9.52 \%$ \\
5 classes primary school & $=45.71 \%$ & high school & $=33.33 \%$ \\
High school & $=2.86 \%$ & University & $=4.76 \%$ \\
& & Commercial school & $=28.57 \%$
\end{tabular}

SOURCE: CNSAS, DOSSIER D 19733 VOL. 1, 114-37

peasants. As already mentioned, education is the only element for international differentiation of this group.

Peasants constituted, at least from this perspective, a very homogenous group, especially when compared to traditional crafts and employees (see Table 12).

\section{The Rise of Legionary Movement in Vâlcea (1934-1938)}

The growth from 81 members in June 1934 to 467 during the first half of 1937, rising to 1,347 in February 1938 is certainly spectacular, but not extraordinary if it is compared with other cases especially in southern Romania. A study of around 1,500 Legionary leaders in lowland Valachia (Greater Bucharest area and south-east Muntenia) confirms the data for Vâlcea: ${ }^{61} 1937$ was the decisive year for Legionary mobilization in Romania, and this is particularly true for areas outside early Legionary strongholds like Bucovina or parts of Moldavia.

In assessing the actual strength of the Legionary Movement it is crucial to consider the relationship between its members and its sympathizers. 'Sympathizers' was a category used by state authorities and by the movement itself, which had established the 'Friends of the Legion' as camouflage organization for members of the Romanian social elites. Data derived from police reports from other parts of Romania allow us to establish a ratio of 1 : 5.06 between party members and sympathizers. ${ }^{62}$ If we transpose this to our

\footnotetext{
61 Ibid.

62 Oliver Jens Schmitt, “Eine mächtige Bewegung auf den Dörfern”: Mechanismen der politischen Mobilisierung der rumänischen Legionärsbewegung im ländlichen Raum
} 
Vâlcea case study, we could assume 6,815 sympathizers or a total of 8,162 persons affiliated directly or indirectly to the Legionary Movement.

However, in the elections of December 1937, the Legionary party only obtained 5,567 votes. The ratio of Legionaries to votes is 1:4.13, and this number confirms at a first glance theories about the limited mobilization potential of the Legionaries, i.e. that the movement was not able to overcome relatively narrow limits of members and a close group of sympathizers - in other words, there was a very modest multiplication factor and Legionaries were hardly able to mobilize outside their own ideological community. ${ }^{63}$ However, one has to be careful with this data: elections in Romania were far from free. Certainly the 1937 elections were probably the least 'guided' in interwar Romania. But Vâlcea belonged to those areas which remained under close government control. Apart from that, one has to bear in mind that many Legionaries were too young to vote and therefore do not appear in electoral statistics.

A comparison with other counties will help us to contextualize our data for Vâlcea. In Romanaţi, another district in Oltenia, police forces counted 647 party members and estimated 3,900 sympathizers in 1937. These 4,547 Legionaries constituted $1.68 \%$ of the county population. The Legionary party obtained $11.66 \%$ of votes in Romanaţi in December 1937. Similar relations between the percentage of Legionaries/County population and votes in December 1937 can be established for a sample of counties which were put together in a police analysis. Unfortunately, this police report does not explain why several counties in north-east Romania and a single county from Oltenia (Romanaţi) were combined in one report. However, this is still the best data series we possess for the entire territory of Romania (see Table 13).

It is obvious that the two cases from Oltenia (Romanaţi and Vâlcea) had similarities (Legionary score of slightly more than $11 \%$ ), but, if we maintain our

(1933-1937): Vorskizze zu einer Sozialgeschichte der "Eisernen Garde", in Nation, Nationalitäten und Nationalismus im östlichen Europa, ed. Marija Wakounig, Wolfgang Mueller and Michael Portmann (Vienna: LIT, 2010), 389-418, here 418; the ratio is lower in traditional strongholds like Câmpulung (3.8), Rădăuţi (4.02), Suceava (4.76), it is high in areas like Romanaţi in Oltenia (6.o2).

63 Heinen, 'Wahlmaschine'; Traian Sandu, 'Der Ertrag der Militanz und der regionale Erfolg der Eisernen Garde: Eine Analyse des Wahlverhaltens und die Folgerungen für die Theorie,' in: Inszenierte Gegenmacht von rechts, 155-90; the problem of this study is that the database is unreliable if not wrong. Sandu operates with a partial statistic (188-190) of nationwide 16.499 members of the party 'Everything for the fatherland'. According to these data, Vâlcea had only 185 members. For a discussion of data published by Schmitt, “'Eine mächtige Bewegung”' cf. Sandu, 'Der Ertrag der Militanz,' 16o-61. 
TABLE 13 Potential of mobilization: ratio votes/Legionary members and sympathizers December 1937.

\begin{tabular}{|c|c|c|c|}
\hline 1. County & 2. Legionaries/population & 3.Votes Dec. 1937 & 4. Ratio $2 . \& 3$. \\
\hline Romanaţi & $1.68 \%$ & $11.66 \%$ & 6.9 \\
\hline Rădăuţi & $2.8 \%$ & $32.4 \%$ & 11.5 \\
\hline Baia & $0.75 \%$ & $10.68 \%$ & 14.24 \\
\hline Suceava & $3.47 \%$ & $23.55 \%$ & 6.7 \\
\hline Câmpulung & $2.65 \%$ & $32.85 \%$ & 12.2 \\
\hline Storojineţ & $1.16 \%$ & $14.08 \%$ & 12.13 \\
\hline Dorohoi & $0.64 \%$ & $6.7 \%$ & 10.46 \\
\hline Average & $1.87 \%$ & $1 ., 84 \%$ & 10.59 \\
\hline Vâlcea & $2.9 \%$ & $11.35 \%$ & $3 \cdot 9$ \\
\hline
\end{tabular}

SOURCE: SCHMITT, 'EINE MÄCHTIGE BEWEGUNG,' 418

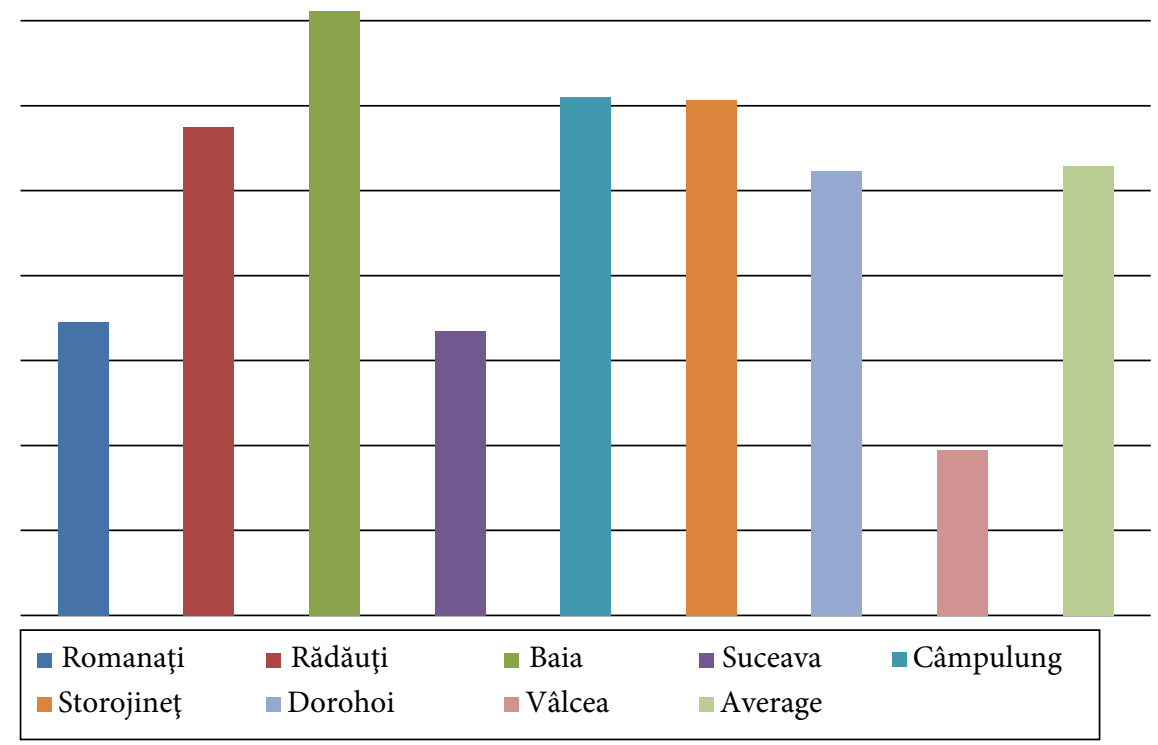


estimate of party members and sympathizers, we have to explain a considerable difference in the mobilization potential (3.9 in Vâlcea, 6.9 in Romanaţi). The data suggests that the percentage of Legionaries in Vâlcea was smaller. But they do not provide a consistent feature. Legionaries succeeded in overcoming the narrow limits of their political community in areas where there had put down roots rather early, i.e. in the late 1920s (Rădăuţi, Câmpulung), while in areas where mobilization had begun at a later stage - and this was definitely the case of most of Oltenia and Muntenia - the Legionary party was supported electorally by a core group of members and sympathizers (Romanaţi, Vâlcea). In Suceava, however, which belonged to the early heartland of the movement in Moldavia, the mobilization potential was more limited than in other Legionary citadels in Moldavia. Closer scrutiny of other data from north and north-east Romania (Baia, Storojineţ, Dorohoi) reveals that considerable regional differences have to be integrated into models of interpretation: in north-eastern Romania and in the Maramureş region in northern Romania, with their numerous Jewish communities and traditions of political antiSemitism, the Legion could rely on more fecund political ground that did not exist in Valachia.

\section{Conclusion}

In conclusion, our Vâlcea County case study confirms interpretations of an analysis of local Legionary leaders in the Greater Bucharest area. Southern Romania was integrated relatively late into the wave of Legionary mobilization that had started in north-eastern and eastern Romania in the late 1920s and early 1930s. It never obtained the intensive momentum of radical mobilization as more industrialized areas in Banat and Transylvania or traditional strongholds of the movement in Moldavia. Until 1936, the Legion was unable to penetrate southern Romania with the exception of isolated spots whose existence is to be explained by the transmission of ideology and practices to village communities by students and young professionals. The high tide of regional mobilization began when the movement reached its nationwide apogee in 1937. It was only then that the Legionaries obtained support from new social strata, i.e. the overwhelming peasant majority. Before, its core groups - students, and some intellectuals with an average age of around 31 years - had remained rather isolated. The extensive recruitment of peasants was certainly due to the effects of the world economic crisis, but also due to the strategy of 'constructive work' in rural Romania - Legionary work camps had a considerable effect on local political mobilization. These work camps were usually established by local 
leaders and integrated local communities into the Legionary world of beliefs, practices and values.

It is not untypical that Legionary mobilization in Vâlcea was not conducted by Corneliu Codreanu, but by regional leaders who enjoyed social prestige on the spot. In Vâlcea, as we have seen, the key figure was a politically ambitious local bishop, but without village intellectuals as means of transmission between the regional center and the villages and without regional students who maintained close contacts with the national center in Bucharest, Legionary entrenchment in a government fief as Vâlcea would have been impossible. Despite the importance of clergymen in this process, it has to be emphasized that even in Vâlcea with its Legionary bishop the movement was far from being an example of clerical fascism. The overwhelming peasant majority of members joined the movement when it started to implement its strategy of a parallel society competing with state institutions and promising a better life in an egalitarian Romanian national community. ${ }^{64}$ There are clear indicators that village intellectuals dominated leadership positions in the movement. Indeed, one might argue that better educated local elites joined the movement as a community of creed and values, while the mass of peasant members took Codreanu's slogan of a better life in a Legionary Romania literally. They were not waiting for the creation of a Legionary New Man, they wanted a social revolution. The mass of peasant members had lost confidence in constitutional parliamentarism which had failed to integrate the overwhelming majority into the political and social system of "Greater Romania". What they strove for was not a 'New Man' but a radical redistribution of political power and economic resources.

64 The theory of a Legionary parallel society is developed in Haynes 'Work Camps, Commerce, and the Education of the "New Man".' 


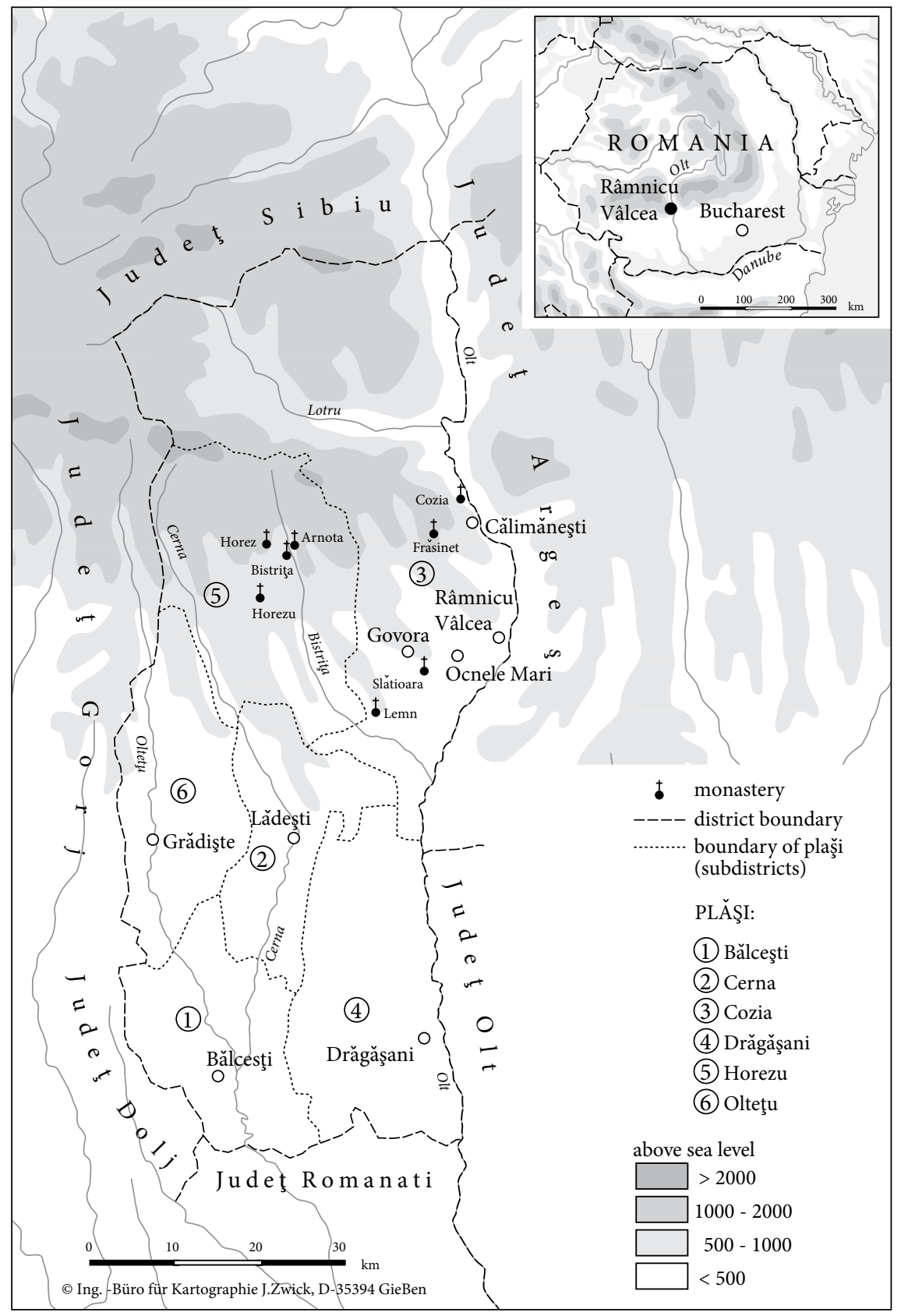

FIGURE 1 Vâlcea county 